\title{
The (Bio)political Novel
}

Some Reflections on Frogs by Mo Yan

\section{Yinde Zhang}

Translator. Jonathan Hall

\section{(2) OpenEdition}

\section{Journals}

Electronic version

URL: http://journals.openedition.org/chinaperspectives/5748

DOI: 10.4000/chinaperspectives. 5748

ISSN: 1996-4617

Publisher

Centre d'étude français sur la Chine contemporaine

\section{Printed version}

Date of publication: 30 December 2011

Number of pages: 53-61

ISSN: 2070-3449

\section{Electronic reference}

Yinde Zhang, «The (Bio)political Novel », China Perspectives [Online], 2011/4 | 2011, Online since 30 December 2014, connection on 28 October 2019. URL : http://journals.openedition.org/ chinaperspectives/5748; DOI : 10.4000/chinaperspectives.5748 


\title{
The (Bio)political Novel
}

\author{
Some Reflections on Frogs by Mo Yan
}

\section{YINDE ZHANG*}

\begin{abstract}
The political concerns underlying Mo Yan's creative work come to the fore in his latest novel, Frogs (Wa), which gives the reader an unusual perspective on the complex relations between fiction and politics. This novel harshly criticises a state whose coercive population control policies are responsible for some murderous consequences. This denunciation is also aimed at the economic ultraliberalism that is complicit with the totalitarian inheritance in destruction of human dignity through the alienation and commercialisation of the body. The complex symbolic structure of this work brings out the need for life itself to be rehabilitated in accordance with basic human rights and membership in the human community, and to be strongly defended against political attack and moral decay. Far from being an essentialist communitarian ethics, however, the bioethics proposed by the author offers the possibility of social reconstruction of the bios.
\end{abstract}

\section{KEYWORDS: Mo Yan, Frogs (Wa 蛙), the (bio)political novel}

l: the field of contemporary Chinese literature Mo Yan 莫言 (1956- ) has a special place owing to the continually striking and even bewildering images in his ongoing literary output. From his Wineland to Life and Death are Wearing Me Out, through Sandalwood Torture to Big Breasts and Wide Hips, his works invariably display scenes of cannibalism, cruelty, and violence that excite and divide critical opinion. These often-discussed aspects of his work actually conceal an underlying political energy, which comes to the fore in his latest novel Frogs $(W a)$, ${ }^{(1)}$ giving the reader an unusual perspective on the complex relations between fiction and politics.

From the very outset, this writer has recognised that his work is inextricably linked to politics, as is made clear in his introduction to The Garlic Ballads ( Tiantang suantai zhi ge 天堂蒜薹之歌), a novel published in 1987: "The novelist always tries to keep clear of politics, but the novel itself inexorably draws closer to it." (2) Although this declaration is toned down in subsequent editions, the author has never repudiated this inner conviction, which finds an outlet not so much in overt commitments as through its literary reconfiguration. While the basic impulse of this novel is a plea on behalf of the shamefully exploited peasants, it gives precedence to fiction over factual reporting, deliberately mixing the language of the media with a blind man's song and tales of imagination. In this filtering and remoulding of politics, Mo Yan resembles Yan Lianke 閻連科, author of The Dream of Ding Village ( Dingzhuang meng 丁莊夢), a committed work that avoids documentary realism. ${ }^{(3)}$

Frogs represents a further step in "testing the political" within a dialectic that refracts politics through the prism of literary discourse. ${ }^{(4)}$ The novel is divided into five sections, but in reality it consists of two halves, the first of which presents the dramatic events arising from the compulsory abortions of the 1960s, and the second the no less tragic story, in a more recent context, of a surrogate mother deprived of parental rights. The drama revolves around the personality of a politically committed gynaecologist who is the narrator's aunt and has accomplished heroic deeds in applying the birth control policy in Gaomi 高密, which combines the author's own birthplace with his imagined republic. It is an epistolary novel in which the narrator writes to a Japanese writer friend, who is called Sugitani Yoshihito 杉谷義人 but whose barely concealed identity is really Kenzaburo Oe. ${ }^{(5)}$ However, the fifth and final section marks a shift into drama, incorporating a play with the same title as the novel. This sophisticated shifting across genres is nonetheless organised in a way that leaves no doubt about the work's actual field of reference; the freshness of certain events in the collective memory makes it impossible to read it as pure fiction. It is also quite transparent in its allusion to certain episodes in recent history, such as the abusive compulsory sterilisation and abortion campaigns conducted in Linyi 臨沂, Shandong Province, which is in fact the author's birthplace. (6) Similarly, the name given to Chen the Eyelash (Chen Mei 陳眉), (7) the

Yinde Zhang is a professor of Chinese studies at the Sorbonne Nouvelle-Paris 3, where he is also senior researcher of the Centre for comparative research studies and a member of the Centre for the study of modern and contemporary China (EHESS/CNRS). His own research is in the field of contemporary Chinese literature and Sino-Western relations in the twentieth and twenty-first centuries.

1. Mo Yan, Wa (Frogs), Shanghai wenyi chubanshe, 2009; French translation, Grenouilles, by Chantal Chen-Andro, Éditions du Seuil, 2011. Throughout the present article, my bracketed page references are to these two editions, the first being to the Chinese version and the second to the French.

2. Translated into French as La Mélopée de l'ail paradisiaque by Chantal Chen-Andro, Seuil 2005. Her translation of the Introduction differs slightly from ours. For the original version, see Mo Yan, "Preface" to Tiantang suantai zhi ge, Beijing, Dangdai shijie chubanshe, 2003, p. 1.

3. After conducting several investigations, this writer gave up reporting in favour of fiction, in order to denounce the scandal of the AIDS epidemic ravaging the villages of Henan, which fell victim to unregulated blood transfusions. Yan Lianke's work was translated into French by Claude Payen as Le Rêve du Village des Ding, Philippe Picquier 2007; for a critical appraisal see Sebastian Veg, "Yan Lianke, Le Rêve du Village des Ding," Perspectives Chinoises, 2009/1, http://www.cefc.com.hk/pccpa.php?aid= $2403 \&$ lg=en (consulted on 20 January 2011)

4. This expression comes from Claude Lefort, Écrire : à l'épreuve du politique, Paris, Calmann-Lévy, 1992.

5. See the interviews between Mo Yan and the Japanese Nobel prize winner, "Zuowei laobaixing xiezuo 2002 nian yu Dajiang Jiansanlang, Zhang Yimou duihua" (Writing for ordinary people: Interviews with Kenzaburo Oe and Zhang Yimou), in Mo Yan, Duihua xin lu (New interviews), Beijing, Wenhua yishu chubanshe, 2010, pp. 490-532.

6. On the abusive campaigns and the imprisonment of Chen Guangcheng 陳光誠, a blind lawyer and champion of human rights, see Leïla Choukroune, "Ces courageux avocats chinois," Libération, 5 December 2006. The future Nobel Prize winner Liu Xiaobo mounted a defence of this lawyer in an article published on 10 September 2005: "Mumang xinliang de Chen Guangcheng xiansheng" (Mr. Chen Guangcheng, blind but clear-sighted), www.boxun.com/hero/luxb/430_.shtml (consulted on 20 January 2011).

7. I have given the translated names of the characters, followed by their original names in brackets, when they are first mentioned. 
pregnant mother disfigured in a fire that destroyed the Dongli cuddly toys factory (Dongli maorong wanjuchang 東麗毛絨玩具廠) in Southern China (pp. 230 and 275), unmistakably recalls the fire on 19 November 1993, that destroyed the Zhili toy workshops in Shenzhen (Shenzhen Zhili wanjuchang 深圳致麗玩具廠), when 87 male and 85 female workers lost their lives. ${ }^{(8)}$ These dramatic events can easily be identified, whereas others form part of a diffuse range of facts that are perhaps of greater concern because of the way they continue to nag at the social unconscious, as can be seen by the profitable trade in artificial insemination. This openness to political and social realities does not result in a roman à clef or a work with a message, but rather in a whole network of meanings in which the political undergoes a far-reaching reconfiguration.

Criticism in mainland China dealing with Frogs tends to focus on its moral aspects, by taking the aunt's tale as an allegory of redemption. ${ }^{(9)}$ Some commentators try to read it as a description of the catastrophic consequences of the repressive population control policies, by applying Foucault's theory of biopolitics. ${ }^{(10)}$ But to limit this novel to a theme already somewhat outdated by a relaxation of the corresponding policies in the real world, and focusing only on its criticism of state coercion, is to cut the work off from its infinitely more complex narrative web woven around the figure of the surrogate mother, and to water down the critical power of its engagement with the continuity between the totalitarian heritage and the destructive aberrations of unbridled liberalism. ${ }^{(11)}$ This critical silence about the second half of the novel is comparable to the lack of serious debate on the question in China. Similarly, bio-ethical studies by specialists still give little attention to the area of surrogate pregnancy, focusing rather on the essentially bio-medical or even deontological aspects, such as gene therapy, organ transplants, the regulation of genetically modified material, or the control over assisted pregnancies largely from the perspectives of bio-technology. ${ }^{(12)}$ Thus, in China, the awareness of the bioethical problems raised by the exponential increase in the numbers of surrogate mothers, in terms of legal provisions, the family status of the child, and the psychological and social consequences for both the surrogate mother and the prospective parents have grown very gradually. ${ }^{(13)}$

In this context, Frogs gives rise to three lines of reflection needed for grasping the possibility of a truly insightful reinvention of (bio)politics. Firstly, the novel fiercely criticises the coercion by a state that, burdened by a heavy totalitarian heritage, instigates population policies leading to murderous consequences. The compulsory abortions show government practices dictated by bio-power, which transform biopolitics into "thanatopolitics" (politics of death). Running parallel to this is economic ultra-liberalism, which is a field of countless disasters and excesses such as human trafficking under the cover of surrogate pregnancy, which destroys human dignity through the alienation and commercialisation of the body. The devastating effects of the market, compounded by the lack of government oversight and the absence of political liberalism, are shown as threats to individual liberties and human values. Finally, through the deployment of its complex symbolism, the novel expresses its championship of life, rehabilitated as the basic right of all to their individuality and their membership in the human community, which must be defended against political attack and moral decay. But far from being based on an essentialist communitarianism, the bio-ethics that raises questions within the group leads to a humanism based on relationships and made possible through rebuilding social links and the overall public sphere.

\section{The criticism of bio-power as a totalitarian heritage}

The deadly bio-power denounced by the author is embodied in the strange character of the aunt. In effect, she is a personification of the incoherent population policy that, while improving the population's standard of living, paradoxically degenerates into a "thanatopolitics." The accusatory posture adopted by the author is nonetheless accompanied by a nuanced attitude that reveals the aunt as an ambivalent figure combining midwife with murderer who undergoes a complicated act of expiation.

Firstly the writer provides a temporal framework for her characterisation, and this contextualises her repressive acts. His scrupulous attention to periodisation allows him to be precise in dating and closely tracing the vacillations and shifts towards radicalisation in government policy. The novel introduces a clear break in this chronological record, because it describes the draconian birth control measures implemented in the late 1970s as the direct consequence of their opposite, the anti-Malthusian policies that intensified in the 1950s. So it was the initial political incoherence that gave rise to the series of outrageous counter-measures later. At first, the operations were conducted in a progressive and flexible manner, but in the face of the unwilling population, they hardened to the point of forcing people to undergo compulsory sterilisation and abortion.

The life story of the aunt, who remained long unmarried, is closely matched with this wider history, and her experience merges with that of the People's Republic that used her as a law-abiding, servile, and efficient tool. (14) Daughter of an anti-Japanese resistance hero, and trained in a nursing school set up in the liberated zones, after 1949 she serves as an obstetrician before becoming head of the gynaecological service attached to the clinic of a People's Commune. The political shifts of fortune of which she herself has been a victim - the flight of her fiancé to Taiwan in 1956 and the public humiliation sessions during the Cultural Revolution - have only a superficial effect on her saintly image as a midwife to whom all the babies of the narrator's generation in the township owe their birth. Her un-

8. This dramatic event drew sociologists' attention to the precarious working and living conditions of migrant women workers. See Tan Shen et al., "Qixue zhuizong: yuan Shenzhen zhili wanjuchang 11. 19 dahuo shouhai dagongmei diaocha jishi" (Memories of blood and tears: Enquiries into the young female migrant workers who were victims of the fire at the Zhili toy factory in Shenzhen), Tianya (Frontiers) no. 3, 2001, pp. 4-22; and no. 4, 2001, pp. 71-81

9. Lu Kehan, "Wa: dangdai Zhongguo de zui yu fa" (Frogs: Crime and punishment in contemporary China), Yangzijiang pinglun (Yangtze River critical review), no. 3, 2010, pp. 75-78.

10. Michel Foucault, Naissance de la biopolitique, course given at the Collège de France (1978-1979), Gallimard-Seuil, collection "Hautes études" 2004.

11. See Zhang Meng, "Shengming zai minjian: Mo Yan Wa pouxi" (Life returns to the people: Analyses of Mo Yan's Frogs), Nanfang wentan (Southern Cultural Forum), no. 3 2010, pp. 52-54; Wu Yiqin, "Yuanzui yu jiushu: du Mo Yan changpian xiaoshuo Wa" (Original sin and salvation in Frogs by Mo Yan), ibid., pp. 43-45.

12. See the articles on bio-ethics in China, in Journal international de la bioéthique, vol. 19, no. 4, 2008.

13. Zhang Yapeng, Miu Nannan, and Wu Qiang, "Daiyun yinfa de lunli wenti" (Problems raised by surrogate parenthood), Dangdai yixue yanjiu zazhi (Studies in contemporary medicine) [online]: www.nur136.com/ddyx/showart.asp?cat_id=23\&art_id=509 (consulted on 16 November 2010). See also Meng Haiyan et al.," "Daiyun jishu de lunli yu falü sikao" (Ethical and juridical reflexions on surrogate pregnancy techniques), Yixue yu zhexue (Medicine and Philosophy), no. 7, vol. 29, 2008, pp. $42-44$

14. The political theme of the single child appears in embryonic form in Mo Yan's work as early as 1985 in a novella entitled Baozha (Explosion). This title refers both to the explosive demographic situation that underlay the implementation of draconian measures, and the angry outbursts of the narrator's father when he learns of his daughter-in-law's intention to abort her second pregnancy. The character of the aunt first appears here, before being developed much further in novel. Moving on from the overall attitude of resignation characteristic of the novella, the novel takes up a more sceptical, even condemnatory attitude towards the death-dealing policy fervently championed and carried out by the aunt. See Mo Yan, Explosion, translated into French by Camille Loivier, with a preface by Chantal Chen-Ando, Caractères, 2004. 
challengeable pedigree and her unfailing loyalty to the Party give this venerable midwife a legitimacy above suspicion, but they also demand from her a moral blindness that very soon degenerates into an uncontrollable destructive madness completely in thrall to ideology and to a state apparatus devoid of all traces of humanity.

This revolutionary executioner carries out her lofty deeds in three successful commando operations that illustrate the breadth and the violence of the disaster caused by the repressive policy. The sterilisation of males, which takes on a burlesque tone, is only a prelude to the unconditional destruction of foetuses, which culminates in some murderous dramatic incidents. In three separate stories, the same macabre and deadly scenes are repeated: Geng Fenglian 耿鳳蓮 is drowned while trying to escape, Wang the Bile (Wang Dan 王膽) dies in similar circumstance, leaving her premature baby an orphan, and Wang Renmei 王仁美 is murdered on the clinic's operating table.

One of the bloodiest episodes in the tale of the aunt's murderous heroism occurs in Chapter Nine of the second half. This relates the capture of the narrator's wife, Wang Renmei, who is "guilty" of a second pregnancy, and it probes the impassive mask of the fanatical state executioner. The campaign aimed at rooting out the fleeing woman in fact reveals a character possessed by demonic violence. This is expressed above all by her verbal hysteria. The aunt, who is in command of the campaign, identifies with her role as spokesman for official propaganda. Her "exalted" ( kangkai ji'ang 慷慨激昂 ) voice broadcasts, repeats, and expands upon governmental directives through a loudspeaker mounted on a minibus. It rapidly becomes "hoarse" ( siya 嘶啞) (pp. 126 and 157-8) as she mixes blandishments with invective, and reminders of the regulations with announcements of punishments. She is absolutely intransigent, even while enjoining the fugitive to come out and orchestrating her destructive work with words like: "I know that this might appear irrational" (pp. 130 and 159), (15) but one must "obey" or "execute oneself" in the face of the "overriding reasons" of a state concerned with "the nation's future." Her verbal tyranny is accompanied by her impetuous martial gesticulation. The village takeover has every appearance of a raid carried out by a "work team" made up of "six sturdy militiamen," among others. A minibus carrying a loudspeaker and a caterpillar tractor give a material presence to the dual power of dissuasion, oral and military. With such strong backing, the gynaecologist becomes a military leader "capable of heading an all-conquering army" (pp. 130 and 162). Her imperious and categorical gestures leave no room for ambiguity; when she gives the order to the vice-chief of the department of the people's armed militia, "she raises her right hand... and lowers it suddenly" (pp. 128 and 160).(16) This gesture of fury incarnate anticipates the torture and killing to come, figuratively represented in this passage by the uprooting of the sophora on which the "destiny" of the neighbouring family depends. It "sways and creaks in pain" under the pressure of a cable "digging deeply into the trunk," tearing away a piece of bark and "laying bare the whitish fibres of the wood" (pp. 129 and 160). Human feeling is lost in the face of this tyrannical "monster," who leaves the villagers rooted to the spot in sheer terror.

However, in showing that the terror of her underlings is not misplaced, the author does not merely demonise this character. He also focuses on the deep ambiguities within this apparent executioner, which he traces to her inner drives and the twisted politics of this population control. Half angel, half devil, her hands, as she confesses, are covered with the blood of two types of enemy, the "perfumed" and the "tainted." At the end of the chase that makes Wang the Bile give birth prematurely on a disguised raft, this pursuer "calmly" rebukes her husband, who calls her hands "demon's claws" ( mozhao 魔爪), when she stretches them out to save the baby from danger: "These are not demon's claws but the hands of a gynaecologist" (pp.174 and 208). In her, the murderer lives side by side with the deliverer, whom the villagers even adore to the point of veneration by calling her Guanyin 觀音, the goddess who bestows children and grants the wish for sons ( Songzi niangniang 送子娘娘), and by comparing her to the statue preserved in the temple. But unlike the latter in her immaculate dress, the venerated midwife is dressed in black (pp. 280 and 323), hinting at the ambivalence of her vocation as saviour and destroyer: 2,800 lives cut short are set against nearly 10,000 births (pp. 269 and 322). Do these statistics amount to mitigating circumstances in defence of the officials? At all events she does not hesitate to subordinate the rationality of the State to her own less implacable logic. Admittedly, she is almost unbearable in the way she shows no concern over the often advanced stage of the pregnancy because, according to her, until a foetus has crossed the "threshold of the pot" (guomen 鍋門) it has no existence and must not cause any hesitation over its destruction. Nonetheless, this total absence of bio-ethical considerations contrasts with the compassionate cords of her being when she decrees that once a baby is born it deserves every protection; that is why she adopts Wang the Bile's orphaned daughter, abandoned by a father disinclined to bring up a second female offspring. ${ }^{(17)}$ The banality of evil is exorcised by compassion.

This protagonist's complex character leads the author to raise the question of individual and collective responsibility, making his writing an expiation that also accuses the totalitarian system.

The novel's bipartite structure makes the shifts between crime and penitence quite explicit. The first half sees the aunt caught up in a hyperactive life that contrasts with that of the recluse later when, in the last two sections, she gives herself up to meditation. Her heroic and criminal acts are relayed via the guilty memories that torment her and plunge her into fear and remorse. This repentance only arises gradually, having been overlaid for so long by a mixture of cold indifference and feelings of sacrifice under whose guise the executioner, forgetting the persecution she has unleashed on the population, adopts the stance of a martyr, mistreated by the recalcitrant villagers who promise her the torments of hell (pp. 124 and 162). At the beginning of the fourth section there is a gap, bringing up a hitherto unknown fear: the aunt who had never retreated before anything is struck with panic at the sight of the frogs. Her terror, often assuming fantastic forms, in fact reveals a feeling of guilt that will pursue her until the end of the novel. Disturbed in her sleep, haunted by ghosts and the piercing croaks that evoke the cries of babies more than the sounds of those tailless amphibians, the penitent aunt only justifies her continuing existence by the need to "redeem her faults" and to "undergo suffering and sorrow, like a fish being turned over and over on a grill, or stock being boiled in a pot" (pp. 339 and 408).

This unending repentance is shared, however, by the narrator, who links it to collective responsibility. This man, known as Tadpole (Kedou 蝌蚪), re-

15. But while abusing her authority, the aunt uses an expression that is somewhat ambiguous, to say the least: zhe meiyou daoli, which might mean either "I know that this is not a reason" or "no explanations have to be given."

16. The verb pi denotes moreover a hand brought sharply downwards, "splitting the air."

17. Cf. the novella on the same topic: "Abandoned baby" (Qiying), in Mo Yan, Enfant de fer, stories translated from the Chinese by Chantal Chen-Andro, Seuil, 2004, pp. 207-222. 
peatedly runs through his mea culpa towards his wife, being as much a victim of his own callousness as of that of the gynaecologist, having been befuddled by his ambitious desire to aquire the glorious status of model officer, thanks to his rejection of that second pregnancy. However, this remorse encapsulated in the letter just before the dramatic section of the novel seems to go beyond reflections on individual responsibility. This shift is already introduced by the questions raised at the end of this contrite missive: "Will blood-stained hands remain dirty forever? Will a soul tortured by guilt never be free?" (pp. 281 and 335). (18) These questions are aimed at turning the reader's moral reflections towards more specifically political questions, in the sense that they raise once again the issue of the status of the individual within a definite political system, totalitarian in this instance. This sets up a division in the reader's judgement of the aunt's behaviour: she is to be condemned for her zealous acts that defy moral sense and go beyond externally imposed constraints, but she is justified in terms of her personal choice, which ultimately leads her to transform her reduction to mere instrumentality into an act of individual freedom. The novel brings out this paradox, which is underscored both by events and the narrator's literary reminiscences, specifically the emphatic references to Les Mains Sales (Dirty Hands) and Les Mouches (The Flies) with which the novel opens.

The opening reference to these two plays by Sartre turns them into an epigraph summarising the author's dual attitude towards the aunt. His condemnation means that she will be pursued by the avenging flies drawn to the putrid blood covering her; moreover she is dressed in black (p. 269), no doubt as a sign of mourning and penitence towards her victims, like the inhabitants of Argos. ${ }^{(19)}$ The recourse to the image of the invading flies clearly expresses a condign punishment of the aunt's frenzy that had increased the efficiency of the repressive machine. At the same time, this play between these intertextual references allows the author to reverse the perspective by likening the aunt to Sartre's version of Orestes' willing assumption of his act, thus revealing her capacity for freedom. This takes the aunt beyond her conditioned status to become a paradigmatic full individual, able to oppose the meaning of her existence to the political constraints imposed on it. The ending of the novel exemplifies this split between political power and individual autonomy. The aunt's symbolic death through a failed suicide affirms the death of the totalitarian regime while resurrecting her as a version of Sartre's Hoederer: she reaffirms her identity without really having had to fear dirtying her hands. ${ }^{(20)}$

\section{Bio-ethics in the face of liberalism}

Mo Yan does not stop at his sharp criticism of dictatorial politics by situating them at the centre of episodes relating murderous compulsory abortions. He links them to the scandals around the issue of surrogate mothers in a symmetrically balanced section that uncovers the way in which the totalitarian heritage mutates into a destructive liberalism. The commercialisation of the body under the cover of surrogacy seals the new alliance between the State and unrestrained capitalism. It unveils the social inequalities camouflaged behind the prosperous ostentation, and even further behind that, the unsuspected connivance between official ideology and popular beliefs.

The practice of surrogate motherhood is denounced in Mo Yan's writing because it implies the commercialisation of the body, even in a worthy cause: Chen the Eyelash (Chen Mei) hires out her belly in order to pay the costs of caring for her sick and ruined father. This artificial pregnancy, supposedly to help a sterile couple who are in fact the narrator himself and Little Lion (Xiao Shizi 小獅子), (21) his menopausal second wife, is organised clandestinely by a front company breeding bull-frogs (niuwa 牛蛙) (rana catesbiana). By means of an abominable subterfuge, the surrogate mother is deprived of her promised fee. This episode draws on a well-known story: "The legitimate prince replaced by a cat" ( Limao huan taizi 狸貓換太, also known as Limaohuan zhu 狸貓換主), (22) while giving it an ironic twist. So the old palace intrigues are replaced by a modern drama that competes with them in an ignominious register. In the source text, the rivalry between two concubines pushes one of them to deprive the other of her new-born son by making her believe that she has given birth to a monstrous cat, so that the instigator can put her own son on the throne; similarly in this tale, the surrogate mother is given a cat skinned to make it look like a still-born baby.

This trade in bodies with its mafia-like extortions is just the beginning of a scenario with considerable legal and bio-ethical consequences, because the new-born son is the cause of a merciless war between the biological mother and the prospective couple. In handling this unprecedented situation, which currently faces Chinese society as it is swept off its feet by biotechnological progress without any legal framework, the author feels the need to fall back on archaic symbolism. The legend of the skinned cat is in effect overlaid by the story of the judgement of Solomon, as the novel takes the sting out of the conflict by suspending the decision over the ownership of the baby. There is to be a trial. In the middle of the dramatic fifth section, this trial involves a theatrical parody full of meaningful and far from innocent allusions.

The scene that takes place in the eighth act presents a visual simulacrum of justice, which immediately strikes one with the falsity of the situation. At first a sophisticated overlapping of frames is set up for the reader, because some broadcast television scenes are represented within a theatrical setting, which itself forms part of the novel's diegetic universe. To this already overloaded tale a major chronological dislocation is added, because

18. This translation follows that of Zhang Yinde's article, since the French translation of the novel abbreviated the original Chinese.

19. While blaming the aunt, Mo Yan is in fact deploring the repressive policy of the state. But in this respect his attitude is also rather ambiguous, because even as he condemns the policy, he advances some mitigating circumstances: the radicalism involved is seen as a necessary evil, amounting even to a sacrifice that China was willing to make towards lightening the population pressures on the planet (the French translation of this passage is abbreviated). Starting from a patriotic, even nationalist standpoint, which is to be found in other works such as Sandalwood Torture in particular, Mo Yan defends China's record on population policy and attacks its Western critics: "Western criticism of China's birth control policy is unjust." But this patriotic pride, which he shares with official pronouncements, does not mitigate the author's statements on the domestic scene, especially as, unlike the political Machiavellianism that one might regretfully expect, he levels his criticism at the politics that relies on collective amnesia: "History only attends to ends and disregards the means, just as when we contemplate the Great Wall, the Egyptian pyramids, and other wonders of the world, we do not see the heaps of whitened bones." (p. 177) - in the original text of Wa (Frogs), Mo Yan, op. cit., p. 145.

20. We should recall the emblematic figure at the centre of Les Mains Sales (Dirty Hands), a play written by Jean-Paul Sartre in 1948: Hugo is a young bourgeois who joins the Communist Party in its attempt to fight against Nazism, and has to undertake a delicate mission in order to gain the confidence of his comrades. That mission is the assassination of Hoederer, a Party leader accused of collaborating with the bourgeoisie. Hugo becomes his secretary, gradually discovering in him a friendly protective figure who justifies his actions on the grounds that the ends justify the means. Nonetheless, Hugo resolves to kill Hoederer, whom he discovers embracing his wife. After two years in prison, Hugo declares himself to be "non-recoverable" to his comrades, who have by then made Hoederer a hero and adopted his line of action.

21. I am quoting the French publication here, while recognising that she could be called "Lioness" (Fr. Lionne), since the Chinese does not mark the gender difference.

22. It is taken from an anonymous Yuan dynasty play, Jinshuiqiao Chen Lin bao zhuanghe (Chen Lin carries in his arms a makeup casket on the Golden Stream Bridge) in Zang jinshu (ed.), Selected Yuan dynasty plays, http://club.xilu.com/wave99/replyview-950844-3078.html?PHPSESSID=a0c038a561423ed0f 4be2c6662bf4e (consulted on 9 September 2010). 
the visual décor of the Republican period is supplemented by further anachronistic signs: the court uses the old imperial nomenclature, such as the "residence of the sub-prefect" ( xianya 縣衙), while court guards dressed in the uniforms of Sun Yat-sen's time carry an ancient weapon, a red and black painted "water and fire stick" ( shuihuogun 水火棍). Moreover, the heralds who announce the action defend these distortions, calling such extravagant costumes simply "comic" (pp. 328 and 393).

The layering of the two visual genres, the theatrical and the cinematographic, in the arrangement of these scenes supports the establishment of a trompe-l'oeil effect suitable for representing the travesty that the trial is. The scene in Act Three turns out to be a false duplication: Chen the Eyelash is not really going to meet an exemplary impartial magistrate like the legendary Judge Bao. The play with illusions is made abundantly clear by the avowedly theatrical nature of the judge, to which a further improvisation is added: the actor who is to play Gao Mengjiu 高夢九 immediately becomes Judge Bao when the woman appears as a plaintiff before him.

The abundant evidence of the emptiness of the display is accompanied by another form of demystification that consists of unveiling the corrupt nature of the proceedings and the sentence by demolishing the panels concealing the backstage area, leaving them completely exposed. The paymasters are brought out of the shadows so that their moves are open for all to see. From Yuan the Cheek (Yuan Sai 袁腮), the director of the bullfrog breeding company, and Li the Hand (Li Shou 李手), the restaurant owner, through to the theatre director, their successive appearances achieve the effect of juxtaposing the outward show of the trial with its inner secrets, showing how corruption gains ground and leads the hearings to their perverted outcome. This scene is directly inspired by The Chalk Circle ( Huilan ji 灰欄記) by Li Xingdao 李行道 (1279-1368), but in a way that subverts the original rather than making a pastiche imitation. The original Yuan dynasty play (23) establishes maternal instinct as a reliable criterion for settling the dispute over the child, whereas in this novel the trial is a trap: Chen the Eyelash has lost the case in advance, given that the judicial apparatus sells to the highest bidder. The judge is not personally indifferent to the plaintiff's plight, for he has his "sad and compassionate" ( beice de 悲惻地) side (pp. 331 and 397), as the herald says. This character has a certain resemblance to the figure of Azdak in The Caucasian Chalk Circle by Bertolt Brecht, (24) which was itself inspired by Li Xingdao's play. Brecht's Azdak is a slightly mad trickster who is raised up to the rank of magistrate because of civil disturbances, but who on occasion knowingly pronounces judgments in favour of the lowly. The sentences passed by Judge Gao Mengjiu, whom the local leading lights consider deranged, follow a similar pattern. Despite his unpredictable mood swings - "a gust of wind, a shower, a patch of blue sky" (yizhenfeng yizhen yu yizhen qingtian 一陣風 一陣雨一陣青天) - and his brutality, when for example he brandishes his famous strap as a weapon for dissuasion and punishment, Gao Mengjiu is a spirit inclined towards justice. The difference between him and Azdak is due to the unprecedented corruption surrounding him. The Republican period, that "time of troubles" (luanshi 亂世) (pp. 329 and 395) that was infamous for the criminality of the judiciary, ends up by overwhelming the Chinese magistrate, forcing him to conform, and not allowing him to become, like Azdak, a happy example of the possibilities of chance pitted against the impossibility of justice in a rotten society.

In these circumstances, granting custody of the child to the prospective couple has nothing to do with any legal or bio-ethical considerations. But beyond the legal void and the ethical uncertainties, Mo Yan seeks to focus our attention on the social consequences veiled behind the legal farce. While the Chinese version of The Chalk Circle gives priority to the blood relationship, and while Brecht, by coming down on the side of the kitchen maid, Grusha, against the governor's wife, responds to the criterion of goodness, Mo Yan's Judge Gao stands for the power of money. The corrupt court becomes the place where social inequalities are crystallised and covered over in the clearest possible fashion. When the judge enjoins the plaintiff to uncover her face to speak, and then asks her straightaway to replace her veil, it is basically less out of "compassion" than out of his fear of seeing the hideous social reality in her disfigurement. From the outset, the denial of Chen the Eyelash's situation as victim is due to her socio-economic status, about which the trial is silent. In this way she belongs among the surrogate mothers without any defence in case of litigation, as was shown by the Baby M affair, ${ }^{(25)}$ when a New Jersey court ruled in favour of the prospective parents in the name of "the interests of the child" against a claimant with limited means. Indeed, how could the child have been awarded to a migrant woman ( mingong 民工), give her double handicap, both physical and economic? There is another pressing detail as well: why does the frog-rearing business take such trouble to keep its trade secret, when in reality the sector as a whole is prospering legally, there being no legal requirement, and therefore no official prohibition, interfering with the agencies and websites offering babies as though on a menu, cataloguing the choice of sex and the belly for hire? ${ }^{(26)}$ The real shame belongs to the firm that unscrupulously exploits those disfigured young female workers, now living as pariahs, who no longer have anything but their bodies to sell. These criminal motives, foreseen by the policeman in Act Three, arise precisely from the uncontrolled slide into gangsterism on familiar ground: the networks of prostitution and child-trafficking under cover of legal surrogacy. The candid narrator has the various kinds of service on offer explained to him, including, among others, "insemination by physical contact" (youxing huaiyun 有性懷孕) between the prospective father and the surrogate mother (pp. 302 and 304). Chen the Eyelash, who has earlier re-

23. For the French translation, see Li Hsing-dao, Hoei Lanki ou l'histoire du cercle de craie, translated by Stanislas Julien, London, Oriental Translation Fund, 1832. This Yuan drama tells of a poor girl, Zhang Haitang, who has become the concubine wife of a rich man, Ma Junging, and bears him a child. The legitimate first wife is driven by greed to murder her husband with the complicity of her lover, while also wishing to kidnap the under-age legitimate inheritor. Haitang is accused of the murder and is deprived of her child. Judge Bao, who is famous for his wisdom and impartiality, orders a court official to draw a chalk circle on the ground, and to put the child in the middle: the child is to be awarded to whichever of the two women manages to pull him out of the circle. The poor Haitang loses this "game" because she is afraid of breaking the child's arm, and this convinces the judge of her maternal love and her innocence.

24. Bertolt Brecht, The Caucasian Chalk Circle, trans. Alastair Beaton, London, Methuen, 2010.. We should remember that Brecht was inspired by Li Xingdao's play, which was translated into German and adapted by Klabund. On the figure of the corrupt judge in relation to Brecht's play, see Sebastian Veg, Fictions du pouvoir chinois. Editions EHESS, 2009, p. 167

25. "Case 10: The Case of Baby M," in Tom L. Beauchamp \& James F. Childress (eds.), Principles of Biomedical Ethics, Oxford, OUP, 2001, pp. 430-431. See also Li Junmin, "Daiyun hefahua de lunli wenti yanjiu xianzhuang" (Current situation of ethical questions around legislation on surrogate births), www.daiyunchina.com/newsview.asp?id=252 (consulted on 16 November 2010)

26. In fact, there are currently no legal provisions covering this area. Rulings and administrative measures forbid hospital staff and services from undertaking such practices, but apart from that, the "contracts" are drawn up quite legally, on the free initiative of the two parties via rather murky agencies or other organisations. See "Renlei fuxhu shengzhi jishu guanli banfa" (Regulations on the management of medically assisted pregnancy), published by the Ministry of Public Health, 20 February 2001, and "Renlei fuzhu shengzhi jishu yu renlei jingziku xiangguan jishu guifan, jiben zhunze he lunli yuanze" (Technical rules, and basic norms and ethical principles concerning medically assisted pregnancies and the sperm bank), published by the same Ministry in 2003. At the same time, there are websites offering "fully legal" contracts or "co-operation agreements" such as the following: "Aixin daiyun hezuo xieyi" (A co-operation agreement entitled "Undertaking pregnancy for another out of love"), http://www.daiyunchina.com/newsview.asp?id=123 (consulted on 16 November 2010). 
fused to become rich in Southern China by selling her charms, does not manage to escape this equally dubious trade in bodies (pp. 237-238 and 284).

The courtroom comedy unintentionally replays a social drama and revives an ancestral practice, revealing its affinity with the anthropological basis of modern State ideology. The verdict in favour of Tadpole and Little Lion, to the detriment of Chen the Eyelash, revives an ancient concern with perpetuating patrilineal descent. The recognition of the parental rights of the prospective couple in some ways renews the practice of "therapeutic adoption," according to which, in order to grow up in good health, a baby must be separated from the birth mother, since she is a woman who has been rendered unbalanced, on even been contaminated, by giving birth Separating the child from this dangerous being in order to entrust it to nurses or adoptive parents becomes a necessity that, while conforming to a certain medical discourse and set of popular beliefs, is no less determined by a social structure that treats the young woman as a being not fully separate from the influence of the alien clan. The prophylactic intention behind separating her from her child consists in "neutralising the deregulating power of feminine sexuality and rooting the children firmly in their patrilineal descent." (27) Accordingly, in this novel, the demonic nature that disqualifies the birth mother from her rightful claim to parenthood is expressed in her "madness," coupled with the monstrous face that debars her from all public life: she knows that she is condemned to remain a veiled human being. (28) By way of contrast, it appears quite reasonable to award the child to Little Lion, not so much as a prospective mother, but as a dried-out, desexualised grandmother, which makes her a reassuring figure raised above the disturbed feminine condition. Her status as a protective nurse figure is not only a consequence of her age - she is well into her fifties - but more because of the generation gap concealed beneath the worrying confusion caused by artificially aided pregnancy. Little Lion, who disputes the ownership of the child with Chen the Eyelash, is none other than the latter's adoptive mother: as an assistant nurse she had joined with the aunt in adopting the new-born baby abandoned by her father (pp. 187 and 224), and moreover had later bought a little figurine modelled on the baby's features. The attitude of the narrator reinforces the patrilineal order. He has a premonition of the final and definitive opinion that he confirms at the end of the novel, when he has withdrawn from all its entanglements: "When the mother is unbalanced and can no longer support her own life, it is in the proper order of things that the child should be brought up by the father," since after all he is "that child's biological parent," and that is a fact that the People's Supreme Court cannot set aside (pp. 337 and 405).

The supremacy of the agnatic kinship (patrilineality) order reflects in reality an established consensus that is continually reaffirmed: the principle of male descent justifies the single and unalterable body of the father and the son by excluding the disturbing sexuality of the birth mother and the death-dealing relations between mother and child. Above all, the wish for a child is defined as the wish for a son. Every case of infraction in the novel is explained by this imperative, which in the rural context corresponds to material concerns, but which also mediates the deepest dream of power. This is exorcised in a rather unexpected fashion by artificial pregnancy, revealing a fantasy of dominance shared by the state, society, and individuals alike. From the outset, the birth control policy has been accompanied by overt eugenics, which the state justifies in terms of the need to modernise and strengthen the country, and by a "bio-nationalist project" call- ing for high-quality births. ${ }^{(29)}$ As for the general population, particularly in the countryside, they spontaneously link this way of thinking with the freedom to opt for male descendents rather than with sexual equality. ${ }^{(30)}$ That is how Chen the Eyebrow is flattered, by the assurance that she is carrying an embryo of the stronger sex with "noble genomes." Little Lion resorts likewise to the same arguments to calm her husband when he is surprised to find that his sperm has been filtered and implanted in the belly of another woman (pp. 247-248 and 296). If these two parallel pregnancies, the one of the surrogate mother and the imagined or nervous one of the prospective mother, are at the centre of attention, they are linked primarily to the sex of the future child. From this point on, the artificial construction of male primogeniture becomes paradigmatic of the dream of power that reaches into every field of activity, each being dedicated entirely to the glorification of the nation. So the company that conducts this bio-technical feat boasts proudly of the way its financial and technological performance brings honour to the motherland. Yuan the Cheek, its managing director and a former prisoner sentenced for illegally removing contraceptive coils, proclaims this triumph by having a little national flag put on his desk. This display is aimed at disarming the incredulous, as though he were announcing, "Well, lads, I may be a bandit, but I, too, have the right to be patriotic" (pp. 274 and 328).

Mo Yan seeks to "locate" this generally shared power fantasy by giving it a topographical shape. From this point of view the close proximity between a medical centre and a livestock breeding company introduces an overarching connection between an archaic dream and its resurgence as a modern reinvention in its most terrifying form. The cohabitation of the Sino-American joint capital Family Treasure Hospital for mothers and babies ( Zhongmei hezi fuying yiyuan 中美合資婦嬰醫院) and the aquatic breeding company establishes a disturbing analogy between industrial livestock production and gynaecology, completely merging human pregnancy with a technical form of production contemptuous of human laws. It was her fascinated visit to the Sino-American hospital that made Little Lion decide to become a worker in the factory, with her husband's agreement, and to give birth later amid the frog tanks, at the end of a pregnancy miming that of the surrogate mother. According to the psychoanalyst Monette Vacquin, technical mastery that separates procreation from sexuality and hence from otherness is the indirect expression of the most archaic infantile fantasy of omnipotence, namely the power of reproducing without the other. If one is to give credence to the etymological permutation of the two words for "descent" ( si 嗣) and "resemblance" ( si 似), which form the touchstone of filial piety, the continuity from father to son, thanks to bio-technology, now frees itself from all engagement with differ-

27. Françoise Lauwaert, "Abandon, adoption, liaison. Réflexions sur l'adoption thérapeutique en Chine traditionelle," L'Homme, no. 137, 1996, p. 143. This is also made manifest in vernacular literature, brilliantly analysed by this author.

28. The questions that the aunt and the narrator put to themselves at the end of the novel (p. 337 and 405), over whether it would be right to entrust the child to a "madwoman" and moreover one with a "repulsive face" (zhengning 猙窑), remain unanswered. While the aunt certainly recognises that madness does not prevent anyone from "loving children," this assertion can at best be considered as little more than a confession of remorse over the false testimony she had given to support the dubious claim of Little Lion.

29. Susan Greenhalgh, "The Chinese Biopolitical: Facing the Twenty-first Century," New Genetics and Society, vol. 28, no. 3, September 2009, pp. 205-222, www.socsci.uci.edu/ smgreenh/bio/Greenhalghbiopolitical.pdf (consulted on 19 December 2011). The writer uses the expression "bionationalist project" to refer to a demographic policy that hands population control over to the dream of national power.

30. Isabelle Attané, En espérant un fils... La masculinisation de la population chinoise, Paris, Les éditions de l'INED, 2010 
ence into a desexualised self-engendering. This is enough to flatter "the most archaic unconsciousness within the most cutting-edge science" (31) and to satisfy the maddest desire within the heroes of contemporary success stories, whether in the domain of patriotism, business, or private life, as is shown in this novel by the instructive anodyne pleasantries handed out by a financial sales clerk from the company during a tour of the aquatic facilities. (pp. 224-230 and 268-275).

\section{Social reconstruction of the bios}

Mo Yan chastises the totalitarian order, which is still very much alive and remains a source of moral corruption through its connivance with unrestrained capitalism. But instead of building an alternative political model, he investigates the displacements at work in order to reformulate the ways of questioning the political sphere through a consideration of its social and anthropological implications. Working through a dense network of symbols, he is able to examine the possibilities for rehabilitating human life in its inalienable integrity without sacrificing the bodily realm, envisaged as an integral part of a reconstituted community capable of defending human life against all depredations by liberating modern atomised individuals from their insularity. This new social space heralds a bioethics capable of supporting human dignity.

Through its metaphorical approach, this novel stands first of all for the rehabilitation of life, which is the basis of fundamental individual rights. The murders it charts call at least for a rebuilding, if not for total regeneration. The emotional life of the aunt seems to obey this imperative for reparation, which arrives belatedly but with redoubled force: the former female Doctor Jekyll and determined spinster is transformed into wife and mistress in the company of two master clay sculptors. Their given names - her husband is called Hao Big Hands (Hao Dashou 郝大手) - already refer to the generous healing touch with which, in fact, he has modelled all the babies in the township. Sculpting replaces the gestures of mourning, neither more nor less, while the workshop is turned into a sanctuary (pp. 268-270 and 323-325). The 2,800 figurines, which give a face to the same number of victims of foeticide, are lined up on box shelves with an altar to receive prayers. The ritual is conducted with solemnity despite the intimate setting: the aunt, followed by impromptu visitors, prostrates herself before the altar after lighting "three incense sticks." The mourning is also accompanied by the work of increasing individuation when a name that confirms their identity is added to these already differentiated faces. The baptism thus goes beyond the harm done to affirm a rebirth. The bestowal of each name engenders an etiological narrative that places the statuettes in a long karmic chain. The recall of their genealogies is completed by a description of their respective destinies. This reincarnation, which confirms the triumph of biography over biological fate, is carried out within a precise timescale: after 49 days spent drying - the time the shades must spend on earth before their reincarnation - and after the mourning ceremonies, most of these figurines return to the families waiting to greet them. There they lead a happy existence, unless they choose to remain in their earthen form, but brought to life by the blood that Qin $\mathrm{He}$, the aunt's lover, squeezes out by piercing his middle finger (pp. 184 and 221), and dancing in the moonlight.

The resurrection of the murdered foetuses by means of the modelled figurines derives from rewriting a myth. It refers to Nüwa, the goddess who created men out of clay. ${ }^{(32)}$ But the invocation of this goddess who creates hu- mankind does not only have biological and individual meaning. By fashioning all the babies of the township, the sculptors make her a tutelary deity for the community, giving the beings resurrected in this way a social nature.

The work's anthropological speculations, combined with popular beliefs, invite the reader to grasp this imagined community. Thus, through Little Lion's rhetorical questions, a chain of analogies is set up on the basis of the homophony of wa 娃, 蛙, 媧, which links "baby," "frog," and "the Goddess Nüwa": (33)

Why are the words for "baby" and "frog" pronounced in the same way? Why is the cry of the newborn baby leaving his mother's belly exactly like the croaking of a frog? Why is it that in our township of Dongbei, many of the clay figurines representing babies carry a frog in their arms? Why is the first ancestor of humankind called Nüwa? This homophony shows that the first ancestor was a big frog, and that humankind descends from frogs... (pp. 223 and 267).

The questions raised in this diatribe comprise two different attempts to make connections. The relationship between "baby" and "frog" are supported by the physical resemblances ${ }^{(34)}$ between tadpoles and foetuses at a certain stage of their development, and between the cry of newborn babies and the croaking of frogs. On the other hand, the analogy between "frog" and the Coddess Nüwa is reached by reflecting on symbolisation, or to be more precise, totemisation. The questions are raised in order to introduce the significant reply that there is a triangular relationship between frogs, the creative divinity, and the community: through their somewhat grotesque association with the Goddess Nüwa, the tailless amphibians are deified and raised to the level of ancestors. If Nüwa created mankind, she has delegated to the amphibian the power to protect the township of Dongbei. The cult established to support this divinisation and confirmed by the figurines of the babies with frogs gives the inhabitants the possibility of identifying with the founder of their community, just like the straw-eating clan who set up a mare on their ancestral altar. ${ }^{(35)}$

The totemisation set out in this quasi-didactic passage is spread throughout the work via intertextual references and a network of motifs that mix the sacred with ecological considerations. The tailless amphibians are in effect assimilated into a species that must be protected, or even worshipped, on account of the living being incarnated in them. The sacred aura that surrounds them brings to mind the Frog God of Pu Songling, (36)

31. Monette Vacquin, Main basse sur les vivants, Fayard, 1999, pp. 14-15.

32. Anthologie des mythes et légendes de la Chine ancienne, selected, introduced, and translated by Rémi Mathieu, Gallimard, "Connaissance de l'Orient," 1989, p. 63.

33. With regard to the interrelationships between frogs, the goddess Nüwa, and the babies, there is an abundant popular iconography along with many archaeological objects illustrated by the work of Ye Shuxian, Qianmian nüshen (The goddess with a thousand faces), Shanghai shehui kexue chubanshe, 2004. See chapter 5, "Nüwa and Nüwa," pp. 136-159, where he shows, with the support of images combining the human and the animal, the imaginary interchangeable fertility between frogs, women, and children.

34. This series of questions is preceded by another reflection: "Haven't you seen specimens of three-month old foetuses? They have a long tailpiece, and are just like frogs and toads during their changeover."

35. Mo Yan, Shicao jiazu (The clan of the straw-eaters), Beijing, Dangdai shijie chubanshe, 2004, p. 113.

36. Shiniang, the Tenth, reincarnation of the frog divinities, was married to the bachelor Kun Sheng when their house was invaded by amphibians. It had undergone a series of misfortunes from the day when her husband offended them by mistreating his wife. Peace and prosperity returned when the wife restored respect for them and the rites were correctly observed in the sanctuary dedicated to the god. She then gave birth to two sons. See "Qingwa shen" (The Frog God), in Pu Songling, Liaozhai zhiyi (Chronicles of the strange), Beijing, Renmin wenxue chubanshe, 1989, pp. 1446-1450. For the translation into French, see "Le Dieu Grenouille," in Pu Songling, Trois contes étranges. Récits chinois et illustrations inédites, preface and translation by Rainier Lanselle, PUF/Fondation Martin Bodmer, 2009, pp. 101-111. 
an author worshipped by Mo Yan: as benevolent deities, the frogs engender and bless humankind provided that there is a reciprocal relationship that imposes the duty to establish a cult for them, to show them respect, and to protect them. This feeling overcomes the narrator when he passes by the statue of the bull-frog at the entrance to the breeding factory: the "mournful gaze of his two bulging eyes seemed to wish to convey to me something arising from the depths of time" (pp. 196 and 234). The narrator's aversion to eating the creature - he turns down an invitation to the feast in his honour offering a special menu of bull-frogs - is as much in obedience to ecological principles as to the voice of the oracles: one shall not eat a being with whom human beings have relationships of fertility and inter-changeability, as the aunt feels when she is haunted by the legends (pp. 215 and 259), and as Tadpole, the narrator's own name, also intimates (pp. 197-198 and 237). The respect for that animal has the force of the prohibition of cannibalism, which gives its radical edge to the satire in Wineland, (37) and also of the statement of the need for species to live together in Forty Cannon Shots and Life and Death are Wearing Me Out. ${ }^{(38)}$.

Mythical forces are invoked in order to repair a community falling apart. Unlike the situation in certain other novels by Mo Yan, which tend to be rooted in an unchanging land, the ancestral Gaomi is disintegrating under the steamroller of the frantic urbanisation process that transforms villages into financial centres and commercial quarters. The narrator's parental home has been saved from demolition, but only to undergo a more ironic and lonely fate, since it has been turned into a museum, set amidst highrises, to satisfy the curiosity of tourists. The kind of communal rebuilding undertaken by Mo Yan involves turning away from such chimeric geography towards seeking a more organic configuration. His native and communally shared land is to be constituted rather as a body that must be quite literally "re-membered." Thus the narrator's return to the land after a frustrating stay in the capital has inspired him to revisit not so much certain places as "members" of the dispersed community. The given names of the characters, which nearly always refer to a part of their body, Chen the Eyelash, Chen the Nose (Chen Bi 陳鼻), Yuan the Cheek, Wang the Liver (Wang Gan 王肝), and the Xiao father and son, Xiao Upper Lip (Xiao Shangchun 肖上唇) and Xiao Lower Lip (Xiao Xiachun 肖下唇), are motivated precisely by this double logic: taken individually, these names evoke scattered bodily members that can only be reassembled through a shared social awareness. The narrator's return stimulates a strengthening of the bonds linking the former comrades who, because they still share "gut" memories - as children they all gnawed lumps of coal during a famine are not just parts of a nostalgic network but participants in a new solidarity made necessary, unfortunately, by the present unequal socio-economic situation. They all extend a helping hand to Chen the Nose, the fallen reject of the reforms. This character represents a call for social justice, especially since, being incapacitated and reduced to begging, he dresses up as Don Quixote, as if he needed to invent an alternative employment for himself in order to bear his life as a virtual galley slave (pp. 236-246 and 283-294). There is an ironic note behind this solidarity, but despite its wishful thinking, it nonetheless provides a glimmer of hope for the re-establishment of artificial social connections through an important fabric that may compensate for the loss of spontaneous social connections, such as the family, that have been uprooted to the point of melting into air.

The re-establishment of community relations, along with its social concerns, has a distant connection with communitarianism. The imaginary community that is outlined in this novel is not free of moral intentions. But these are by no means signs of a retreat into itself. They are based in a social space where a humanism of relationships is being built as a new bulwark against the joint attacks of capital and state.

Mo Yan does not evade moral issues, since he makes the totemised and worshipped animal an ambivalent symbol. The sacred images of the frogs, whose representation has been discussed already, are actually in contrast to their repulsive bestiality. Unlike the positive note sounded in Forty Cannon Shots and Life and Death are Wearing Me Out, in this novel animal nature functions rather as a differentiating paradigm to point to the limitations of human nature. The amphibians' dark, slimy, cold skin, and their gloomy, threatening eyes inspire repugnance, not to mention the nauseating stink from the water in the breeding tanks covered with repulsive soapy bubbles. In this form, the monsters come to haunt the aunt, who is the target of repeated nocturnal attacks from this avenging animal in her nightmares. These phantasmagorical attacks are no doubt explicable as reprisals from her brutally murdered victims, but at the same time they show the forces of evil embodied in their own animal nature.

Animal aggression provides a metaphor for deplorable human behaviour, concentrated by way of example in the character of the evil village youth. Thefts, trafficking, and violent attacks are committed by this ferocious adolescent with a body gleaming "like a black mackerel" that allows him to slip away "like a fish" (pp. 256 and 306). This bestiality is an incarnation of evil: capable of "stealing from cripples," he sees evil as good and even takes sides against the latter. Cross-eyed, and with a pair of "eyes like a fighting cock" ( douji yan 班雞眼) (pp. 254 and 304), he expresses a cruel violence that threatens to destroy justice itself. The writer attributes this capacity for harm to a dual "bio-ethical" causality. He sees in this hooligan the bitter fruit of a disturbed parentage and ancestry. In fact, having died after a compulsory abortion, this young man is reincarnated into a different generation: he is reportedly the son of Zhang the Fist ( Zhang Quan 張 拳) and the brother of his daughter Zhang Laidi 張來娣, and is finally born as the grandson of the former and son of the latter (pp. 271 and 325). This birth, carried to completion by the aunt, who sees it as a deserving reincarnation, is in every respect similar to the worrying confusion that affects the status of Little Lion, who is both mother and grandmother following an artificially aided pregnancy. Are there any secret links, like the manipulations of the sorcerer's apprentice, between a policy that gives birth to such outrageous family planning practices and a laboratory that processes surrogate mothers? In any event, the outcome is the arrival of a malicious mutant capable of destroying family organisation and transgressing the community's cultural taboos. At the same time the author brings out a more expected set of causes: the impact of social environment on individual conduct. In this perspective, the depredations committed by this lad are not alien to the village of Dongfeng, which is a lair of bandits and brigands. The filth that characterises this "devil's spawn" in his appearance as well as in his "obscene words" ( zanghua 䯟話) makes him into a vile reject who "undermined the honesty of the established customs in the township of Dongbei." This low being is the material incarnation of the contamination or impurity that must be expelled from the group if the intention is to

37. Mo Yan, translated into French as Le Pays de l'alcool, by Noël and Liliane Dutrait, Seuil, 2000.

38. Mo Yan, translated into French as Quarante et un coups de canon by Noël and Liliane Dutrait, Seuil, 2008; and La Dure loi du karma tr. by Chantal Chen-Andro, id. 2009. See also my own study, "The Fiction of Human Beings: Man and Animal in the Work of Mo Yan," China Perspectives, no. 2010/3, pp. 124-132. 
preserve the social space in which individuals can develop within their shared humanity. ${ }^{(39)}$

It should be emphasised that the hunt for the mutant, just like the expulsion of filth in the form of this "seed of evil-doing" from the township of Dongbei (pp. 254 and 304; pp. 236 and 314) only takes place in a contrastive mode, insofar as the solidarity of the former comrades is established to revive the resistance of a moral community. The helping hand extended to the lame beggar, Chen the Nose, emanates less from individual qualities than from a resurgent collective conscience when his former comrades have their own humanity revealed to them through the reactivation of their social role. This humanism turns away from a Manichean view that would assign character to a predetermined nature. Principles such as compassion, tolerance, and solidarity are brought into being through the demand that also arises out of a situation of violent change, and the consequential need for them to be realigned with the human condition. Humanitarian gestures, in the wake of Kenzaburo Oe - there is a transparent reference to the example of the handicapped son that the Japanese writer cares for (pp. 267 and 319) (40) - are intended to stimulate inter-personal relations, which are particularly important in the moral crisis affecting the whole of contemporary Chinese society.

So the author expounds a humanism based on relationships, doubled by a criticism of society. The final episode, far from being a mere contrivance, acquires a reflexive dimension in which the social scene and the theatrical scene confront and merge into each other. The theatrical space thereby partakes in a real forum, a public space in which around 15 social "protagonists" enter into a "conflictual" dialogue that reshapes inter-personal links. The "ethics of discussion," (41) which gives rise to more tension than the illusion of social cohesiveness, sets Mo Yan's work apart from the television series The Bonds of Blood (Xuemai 血脈), which is centred on a similar story about a surrogate mother. ${ }^{(42)}$ Overcoming the deep social gap that divides the two sides and is itself completely normalised, this TV romance ends with the unexpected reunion between a halfbrother and half-sister, the first being the prospective father and the second the surrogate mother. In this series the inevitable happy ending is marked by the triumph of "family ethics" (43) through a contrived twist in the plot: the verdict on the ownership of the child is to award it to the whole family, barely managing to avoid the scandal of incest. By contrast, Mo Yan takes over this subject to turn it into a matter for critical reflection, relating the bio-ethical confusions to the indifference of the authorities in the face of outrageous social inequalities, and to the boundless dissolution of morality.

To conclude these considerations on the demographic dictatorship, the uncontrolled development of bio-technology, and the social rebuilding of bodily experience, one should be wary of any attempt to reach a definitive conclusion, given the play with displacement and slippages of which Mo Yan is a master. The juxtaposition of the epistolary form, which underpins the sense of the real thanks to its illusion of sincerity, and the dramatic form that imposes the apparent certainty of its illusion, sets up a textual indeterminacy that disturbs the diegesis. As the curtain falls, a series of questions remain unanswered. Basically, who is the young menacing and slippery villain of the village? Has the author moved into a catastrophic world-view by embracing a post-human imagery (44) and destroying thereby every humanist conviction, or, on the contrary, does this maleficent figure perhaps function rather to reintroduce an axiological otherness capable of awakening our conscience over the urgent need to rediscover shared values, grounded in communicational action transcending family limitations? But this strange being, with a power to harm and exponential ability to dominate that simply overwhelm the innocent and unarmed narrator, may perhaps offer another way of approaching the inexhaustible meanings of the title of the novel. The myriad amphibians ultimately allow us to suspect a message encrypted in the palimpsest figure of Jean-Baptiste Grenouille, ${ }^{(45)}$ the hero of Perfume by Patrick Süskind, whose relationship to Tadpole is less metonymic than oxymoronic: unlike that creature lacking in humanity and puffed up with his dream of conquest, Tadpole resolves to grow up as a child, refusing to become an infantile adult imprisoned by a regressive fantasy of omnipotence.

\section{Translated by Jonathan Hall}

39. See Julia Kristeva, Pouvoirs de l'Horreur, p. 80; and Mary Douglas, Purity and Danger: An Analysis of Concepts of Purity and Taboo (1966), translated into French as De la souillure, Paris, Maspéro, 1971.

40. In addition to the two writers' shared enthusiasm for Sartre, who is discussed at the beginning of this novel.

41. Jürgen Habermas, Erläuterungen zur Diskursethik, Frankfurt, Suhrkamp, 1991; trans. Ciaran C. Cronin, Justification and Application: Remarks on Discourse Ethics, Cambridge, MIT Press 1994.

42. A television series in 30 episodes directed by Chen Weixiang (Malaysia) and broadcast by Jinan television from 4 June 2010. See "Xuemai kaibo daiyun mama huati yingping yin zhengyi" (The broadcast of the Bonds of Blood arouses a lot of polemic about surrogate mothers), www.26lady.com (consulted on 20 June 2010).

43. This is observable in the debates around the issue of cloning, where it is the main cause of reluctance to condone it. Cf. Mireille Delmas-Marty, "Le Débat en Chine sur le clonage humain," in Mireille Delmas-Marty and Pierre-Etienne Will, La Chine et le démocratie, Fayard, 2007, pp. 663-680, esp. p. 673. See also the special issue: "Chine" in the Journal international de la bioéthique, op. cit.

44. Dominique Lecourt, Humain posthumain: la technique et la vie, PUF, 2003.

45. Mo Yan openly proclaims his admiration for Das Parfum by Patrick Süskind, pointing to the sensorial overload characteristic of his writing. Cf. "Odeurs de roman," in Annie Curien (dir.), Écrire au présent. Débats littéraire franco-chinois, Editions de la maison des sciences de l'homme, 2004, p. 60. 